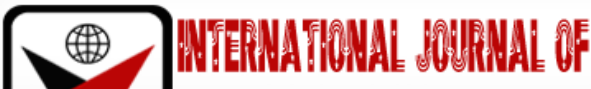

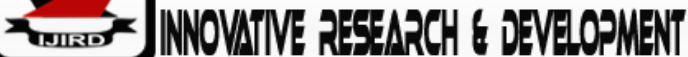

ISSN 2278-0211 (Online)

\section{Priority Strategy Model for Corruption Problem Solving in Indonesia}

\author{
Dicky Iskandar Zulkarnain \\ Trainer, Bogor Environment and Forestry Training Center, Bogor, Indonesia \\ Mochamad Asep Maksum \\ Trainer, Bogor Environment and Forestry Training Center, Bogor, Indonesia
}

\begin{abstract}
:
Corruption is a problem in every country, including in Indonesia. Indonesia has done a lot to solve the problem of corruption, but the results are far from encouraging so far. The research seeks to identify the key elements that contribute to corruption in Indonesia, and with that it seeks to build a conceptual model for a resolution strategy. The research was conducted through a systems approach using the Interpretive Structural Modeling (ISM) method. This research identifies that the key elements of the main causes of corruption in Indonesia are greeds and needs. the strategy for solving the problem of corruption in Indonesia is to prioritize resolving the two main causes of corruption. Furthermore, solving the problem of other main causes, namely opportunity, the influence of the organization's environment, and the pressure of the organization's leadership, must be done simultaneously because it has a high mutual influence.
\end{abstract}

Keywords: Corruption, greeds, main causes of corruption, needs

\section{Introduction}

The level of corruption in Indonesia is still relatively high. This can be seen from the position of Indonesia which has not moved far from the position of a corrupt country as measured by the Corruption Perception Index. The 2019 corruption perception index released by Transparency International on January 23, 2020, contains the results of research on the perception of corruption in a country with an assessment parameter of 0 (zero) meaning that it is perceived as very corrupt and vice versa 100 (one hundred) very clean. Indonesia is ranked 85 out of 180 with a score of 40 . When compared to other ASEAN member countries, Indonesia is in position 4 (Transparency International 2019). This condition is considered to be still worrying, because Indonesia has done many things to reduce the level of corruption. Efforts to eradicate corruption that have been carried out include issuing a Law (UU) for the Special Crime of Corruption, establishing a Special Corruption Crime Court (Tipikor), and finally by establishing a "Super Body" Corruption Eradication Commission (KPK).

Corruption is a behavior that involves the abuse of position or power by public officials for personal gain. According to Shah \& Shacter (2004), the category of corruption includes three types: first, grand corruption, in which a large number of public resources are stolen and misused by a handful of public officials. Second, state or regulatory capture, namely public and private institutions obtaining private benefits by committing acts of collusion. Third, bureaucratic or petty corruption, in which a large number of public officials abuse their power to get small bribes or polish. Bureaucratic or petty corruption is a part of the implementation of policies that are usually carried out by ordinary civil servants and often occur at public service points such as; immigration, police, hospital, tax, licensing, or school services. Meanwhile, grand corruption and regulatory capture are usually carried out by political elites or senior government officials in misusing large amounts of income and public facilities and accepting bribes from national and international companies by designing policies or legislation for their own benefit.

The factors that cause corruption include those disclosed by Jack Bologne et al. (1993), known as the GONE theory. Illustration of GONE Theory related to the factors that cause corruption include; Greeds (greed), Opportunities (opportunities), Need (needs), Exposure (disclosure). However, it is possible that there are other causes that are considered to be problems and the resolution of corruption in Indonesia. Through a systems approach, this research tries to identify the key elements that cause corruption in Indonesia, and with it seeks to build a conceptual model for its resolution strategy.

\section{Methodology}

Priority strategy model for corruption problem solving in Indonesia is approached with a systems methodology, using the Interpretive Structural Modeling (ISM) method. ISM is a structural method that has been used by many researchers to identify relationships or linkages between various elements in solving a particular problem. ISM provides a structured and directional framework for complex problems, and provides decision makers with a realistic picture of their 
situation and the variables involved (Attri et al. 2013). Identification of structures in a system is very useful in handling the system effectively and for better decision making (Saxena et al. 1992).

The main data collection method for this research is through interviews with expert respondents. Expertise is considered from educational background, occupation, and experience. Experts come from practitioners (KPK anticorruption counselors), academics (lecturers), auditors (Inspectorates or Supervisors), other supervisory agencies, and related widyaiswara / trainers. To ensure the appropriate respondents expected the expert criteria, to determine the respondents carried out using a combination of purposive sampling and snowball sampling.

The time for conducting the research, starting from data collection until the completion of the report preparation, was carried out for 6 months, from June to December 2020. The location for data collection was according to the agreement between the researcher and the respondent because of the nature of the interview, while data processing was carried out at the Bogor Environment and Forestry Training Center. Bogor, Indonesia.

The application of the ISM method is carried out in several stages following the flow chart as shown in Figure 1 below.

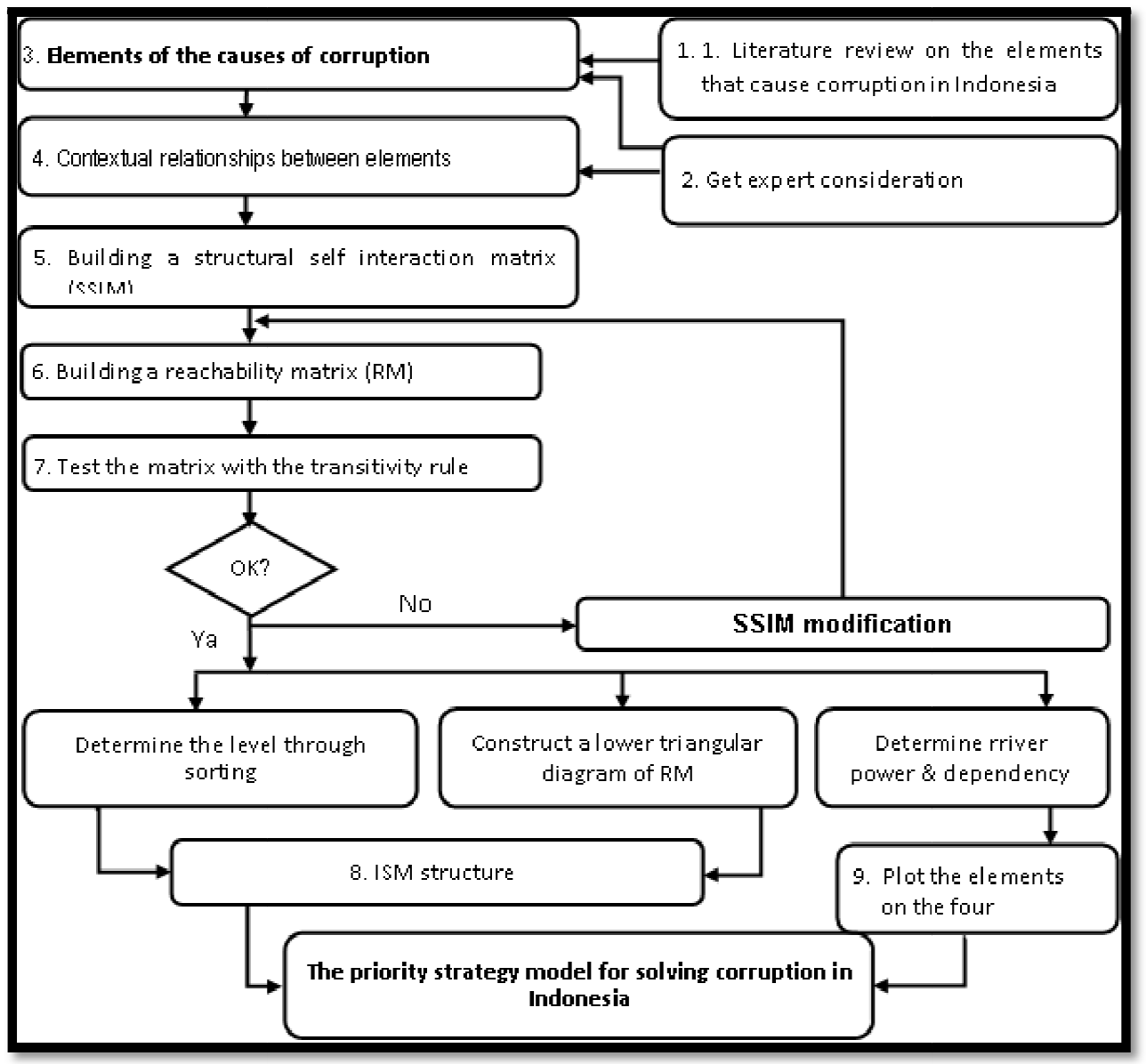

Figure 1: Flowchart of Stages of Applying the ISM Method (Adapted from Saxena 1992)

The contextual relationship between the elements is formulated by building a Structural Self Interaction Matrix / SSIM. The formulation is carried out by assessing the paired contextual relationship in the matrix using symbols $\mathrm{V}$, A, $\mathrm{X}$, and 0 , with the following meanings:

$$
\begin{aligned}
& \mathrm{V} \text { if } \text { eij }=1 \text { and eij }=0 \\
& \mathrm{~A} \text { if eij }=0 \text { and eij }=1 \\
& \mathrm{X} \text { if eij }=1 \text { and eij }=1 \\
& \mathrm{O} \text { if eij }=0 \text { and eij }=0
\end{aligned}
$$

Reachability Matrix (RM) is built by converting SSIM into a binary matrix. This process involves translating the symbols $\mathrm{V}, \mathrm{A}, \mathrm{X}$, and $\mathrm{O}$ into the numbers 1 and 0 . The results of the translation are further corrected to meet the transitivity rule, namely the fulfillment of the completeness of the causal loop. In building and testing the Reachability Matrix, researchers used the SisISM software tool developed by the Bogor Consultant KK.

The final reachability matrix displays the level of each element that will assist in building a hierarchical structure of the priority strategy model for solving corruption problems in Indonesia. The final reachability matrix also contains the thrust and level of dependence of each element on other elements. In order to determine the key elements in the priority strategy for solving the problem of corruption in Indonesia, each of the elements is further grouped based on their driving force and level of dependence into four quadrants (figure 2). The four quadrants are classified as:

- Quadrant I, are autonomous factors. Elements that occupy this quadrant have a weak thrust and dependence on other elements. This element has little or no association with other elements, and therefore its existence in the system does not have much effect. The elements that occupy this quadrant can then be removed from the system. 
- Quadrant II, are dependent factors. The elements in the quadrant are highly dependent and have weak driving force. Therefore the elements that occupy this quadrant are not free, because they are very dependent on other elements in the system.

- Quadrant III, are linkage factors. The elements in this quadrant have a high enough thrust, but also have a high enough dependence. The elements contained in this quadrant require careful study in their application, because they have unstable relationships between elements in the system.

- Quadrant IV, are Independent factors. This quadrant is inhabited by elements that have high thrust and weak dependence (tend to be independent). The elements in this quadrant have a significant influence in the system, and are therefore key factors in building the model.

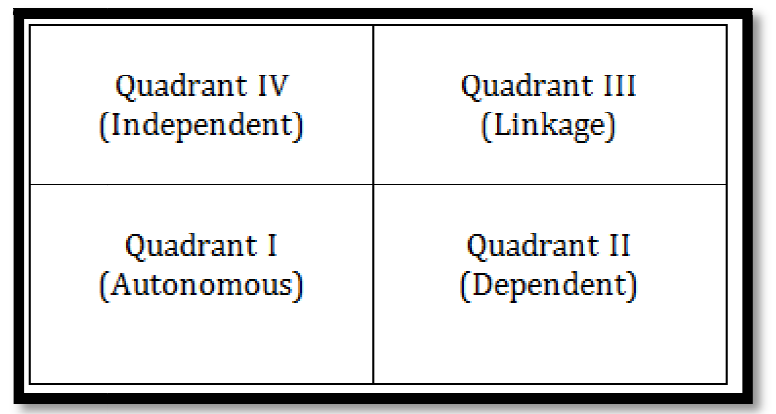

Figure 2. Four Quadrant Groupings of Elements

\section{Results and Discussion}

The main elements of the causes of corruption in Indonesia identified in this study complement the GONE theory that has been frequently used. The GONE theory is a refinement of the Triangle Fraud theory which reveals why a corruptor commits fraud which includes elements of Greed, Opportunity, Need, Exposes. GONE theory describes the causes of corruption based on internal factors that exist in the individual perpetrators of corruption. In this study, two other factors causing corruption were added, namely in the form of the influence of the organizational environment and pressure from the organizational leadership which are external factors (Hasbullah, 2017, Santoso et al. 2014). Therefore, the strategy developed is to consider the six elements that cause corruption, namely: Greeds (E1), Opportunities (E2), Need (E3), Exposure (E4), environmental influences (E5), and pressure from the leader (E6).

The type of contextual relationship pattern between the defined elements is influence. resolving one element of the causative factor of corruption influences the resolution of another element of the causative factor. The results of the aggregation of expert opinions regarding the contextual relationship between elements of the factors causing corruption are as contained in the SSIM table in Table 1 below.

\begin{tabular}{|c|c|c|c|c|c|c|c|}
\hline $\begin{array}{c}\text { Element } \\
\text { Number }\end{array}$ & Causes of Corruption Elements & $\mathbf{6}$ & $\mathbf{5}$ & $\mathbf{4}$ & $\mathbf{3}$ & $\mathbf{2}$ & $\mathbf{1}$ \\
\hline 1 & Greeds & V & V & V & V & V & \\
\hline 2 & Opportunities & 0 & X & V & A & & \\
\hline 3 & Need & 0 & V & V & & & \\
\hline 4 & Exposure & A & A & & & & \\
\hline 5 & environmental influences & X & & & & & \\
\hline 6 & pressure from the leader & & & & & & \\
\hline
\end{tabular}

Table 1: Structural Self-Interaction Matrix (SSIM) of the Elements That Cause Corruption Primary Data Processed from Respondents

Using the software, the data in the SSIM table above is then converted into binary 1 and 0 matrices into an initial reachability matrix (IRM), then corrected with the transitivity principle to produce a final reachability matrix (FRM). Through FRM, the level of dependence and driver power as well as the rank / level of each of the factors causing corruption can be determined. The results of mapping the value of dependence level and driver power generated by FRM into four quadrants are as shown in Figure 3. 


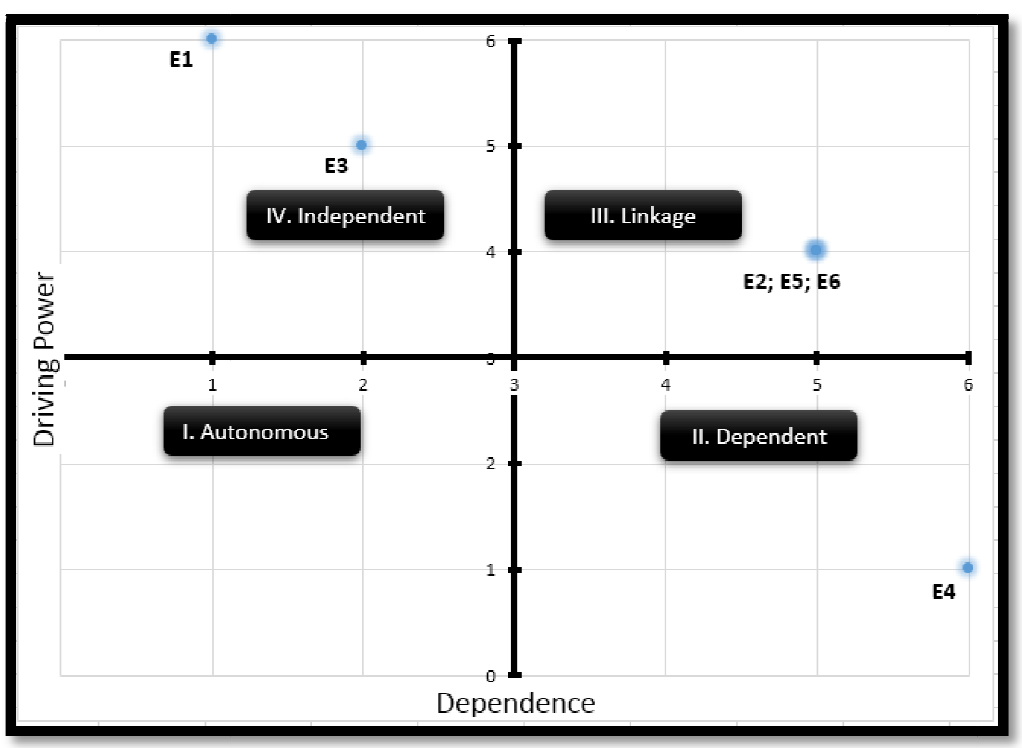

Figure 3: Four Quadrant Groupings of Elements That Cause Corruption

The classification of each sub-element into the driver power and dependence relationship diagram as shown in Figure 3 shows that none of the predefined corruption-causing factor elements occupy quadrant I (Autonomous). This implies that all the elements that cause corruption are determined to have an influence in the system, and therefore no elements need to be removed from the system.

The key elements causing corruption in Indonesia as depicted in Figure 3 above are the greeds element (E1) and the Need element (E3), because they occupy the 4th quadrant. These two elements are key elements because they have high thrust and low dependence. high). This means that the resolution or elimination of corruption problems originating from the causes of greeds and needs, has a high impetus for resolving corruption problems due to other causes. The two elements are also more dominant and less influenced by other elements.

From Figure 3, it can also be seen that the Opportunities element, the environmental influence element and the leadership pressure element occupy the 3rd quadrant or the linkage quadrant, meaning that these three elements have a strong relationship. The resolution of the three elements that cause corruption should be done carefully, or it must be done side by side, because they influence each other. Meanwhile, the exposure element occupies quadrant II (Dependent), which means that the element has high dependence on other elements and has a weak thrust against the system. The influence of the last element is not free, because it is very dependent on other elements in the system.

Hierarchically, the corruption resolution strategy model from the aspects of the main causes of corruption that is built is depicted in Figure 4 below.

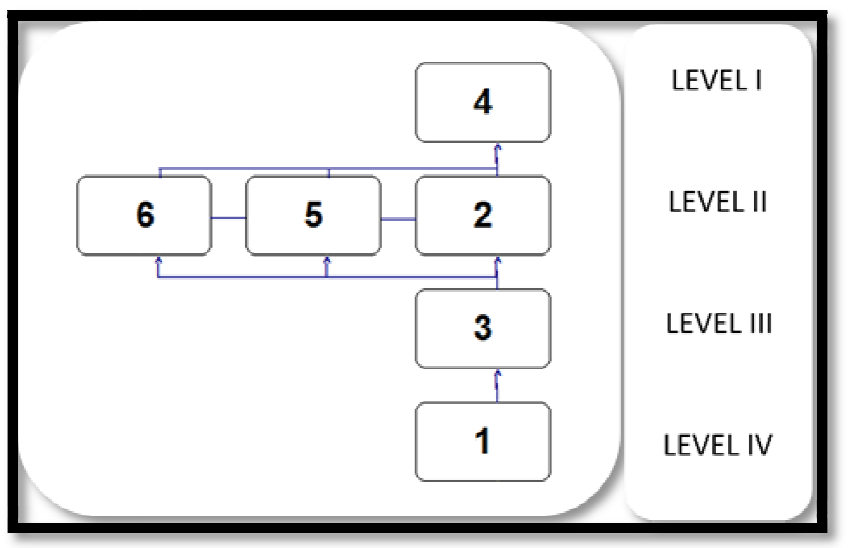

Figure 4: Hierarchical Model of Corruption Resolution Strategies

The Hierarchical Structure Model in Figure 4 above shows that solving the causes of corruption in the form of greed (1) and Need (3) will provide an impetus for resolving the resolution of corruption from other causal elements. This indicates that the first step in solving corruption must begin with solving the problem of greeds and needs.

The Greed factor is the highest priority for problem solving based on the causes of corruption. The greed factor tends to make a person blind to his actions, justifies any means to fulfill his material desires (Dewani \& Chariri 2015), so that the higher a person's level of greed, the higher the potential for committing acts of corruption. Need factor, is the second cause that is important to prioritize resolved. Increased needs (which usually follow lifestyles and the environment) make people do their best to meet them, and can be a driving force for corruption. Some people will do anything to meet their needs even though they have to do corruption. The higher the level of need, the higher the potential for a person to commit corruption. So there is a link between need and greeds, where humans tend to try to get more than their basic needs. Greedy nature makes humans never feel satisfied with what they already have. 
Greeds and needs are the two main factors causing the internal corruption problem in Indonesia. This confirms previous research by Syarief and Prastiyo (2018), that internal factors in the form of individual behavior are the main cause of corruption in Indonesia. Internal impulses appear in the form of desire or intention and do so with full awareness. A person is motivated to commit corruption, among others, because of the greedy nature of humans, a consumptive lifestyle, a lack of religion, weak morality in the face of the temptation of corruption, and a lack of ethics as an official. Resolving individual internal problems, for example through the internalization of basic values of ethics and integrity, even law enforcement, is very important and plays a role in encouraging the resolution of other causes of corruption. Anticorruption education and internalization should not only focus on the cognitive side, but also touch the character side through the development of the basic human values tradition, achievement, power, stimulation, hedonism, conformity, security, positive self direction, universalism, and benevolence (Yuwanto 2015).

After the greeds and needs elements, the next important elements causing corruption to be resolved are related to external factors or outside influences, namely opportunities, the influence of the organizational environment, and pressure from the organizational leadership. These three elements of cause are related or influence each other. Therefore, the solution requires care, and as far as possible be completed simultaneously.

There is one thing that is surprising, that the results of this study place exposure as the element causing corruption that is not prioritized to be resolved, compared to other elements. Perhaps the explanation for this condition is that the element of exposure is not very influential in improving the conditions of corruption, when individuals have a greedy nature where shame tends to disappear, or when environmental factors trigger corruption practices in congregation and become commonplace. The driving force of this exposure element will become even weaker, when the practice of law enforcement against the perpetrators of corruption does not bring a deterrent effect, or a impoverishing effect on the perpetrators. The resolution of the problem of corruption in Indonesia needs to be supported by the commitment of law enforcers in carrying out law enforcement in a firm, consistent and integrated manner, so that the law can create a sense of justice, provide legal certainty, and benefit the community. Law enforcers must have the courage to take decisive steps, prosecute the heaviest sanctions for perpetrators of corruption, both criminal sanctions, fines, replacement money, reverse proof accumulated with money laundering (TPPU), coupled with the provision of social sanctions, thus giving a deterrent effect (Waluyo, 2014).

\section{Conclusions and Recommendations}

This research has identified six elements of the main causes of corruption in Indonesia, namely greeds, need, opportunities, exposure, the influence of the organizational environment and the pressure of organizational leaders. The key elements of the main causes of corruption in Indonesia are greeds and needs. The two elements are independent, and have a high impetus for the system, therefore the resolution of these two elements will encourage the resolution of other elements that cause corruption. Therefore, the strategy model for solving the problem of corruption in Indonesia that is produced from this research is to prioritize solving greeds and needs. This study recommends conducting further research related to the deepening of the elements of greeds and needs, to present a more specific strategic model in solving the problem of corruption in Indonesia.

\section{References}

i. Transparency International. (2020). Corruption Perceptions Indeks 2019. Berlin: Transparency Internasional.

ii. Bologna, J, Lindquist, R.J., \&, \& Wells, J.T. (1993). The Accountants Handbook of Fraud and Commercial. New York: Wiley.

iii. Attri R, Dev N, \& Sharma V. (2013). Interpretive structural modelling (ISM) approach. An Overview. Res. J. Manag. Sci. 2 (2)

iv. Saxena JP, Sushil, Vrat P. 1992. Hierarchy and classification of program plan elements using interpretive structural modeling: a case study of energy conservation in the Indian cement industry. Syst. Pract. 5(6):651670.

v. Syarief, R. A. O. and Prastiyo. D. (2018). Collective corruption in Indonesia: between the causing factors and law enforcement (Korupsi berjamaah di Indonesia: antara faktor penyebab dan penegakan hukum). Jurnal Hukum Respublica. 18(1): 1-13

vi. Waluyo, B. 2014. Optimizing the eradication of corruption in Indonesia (Optimalisasi pemberantasan korupsi di Indonesia). Jurnal Yuridis. 1(2): 169-182.

vii. Yuwanto, L. (2015). Corruptor profile based on basic human values review (Profil koruptor berdasarkan tinjauan basic human values). Integritas. 1 (1): 1-13.

viii. Dewani, R. A. \& Chariri, A. (2015). Money laundering and women's involvement (Artist): A new challenge for investigative auditors (Money laundering dan keterlibatan wanita (Artis): Tantangan baru bagi auditor investigasi). Diponegoro Journal of Accounting. 4(3): 1-6.

ix. Santoso, L. Meyriswati, D. and Alfian I.N. (2014). Corruption and mentality: cultural obstacles in combating corruption in Indonesia (Korupsi dan mentalitas: kendala kultural dalam pemberantasan korupsi di Indonesia). Masyarakat, Kebudayaan dan Politik. 27 (4): 173-183.

x. Hasbullah. (2017). Orders of superiors or positions (ambtelijk bevel) as a cause of corruption in the bureaucratic environment (Perintah atasan atau jabatan (ambtelijk bevel) sebagai penyebab korupsi di lingkungan birokrasi). Jurnal Muara Ilmu Sosial, Humaniora, dan Seni. 1(1): 89-94. 